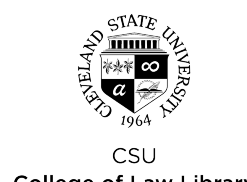

Cleveland State University

College of Law Library

\title{
EngagedScholarship@CSU
}

1999

\section{Analysing the Extraterritorial Application of the National Environmental Policy Act}

Browne C. Lewis

Cleveland-Marshall College of Law, Cleveland State University, blewis39@nccu.edu

Follow this and additional works at: https://engagedscholarship.csuohio.edu/fac_articles

Part of the Environmental Law Commons

How does access to this work benefit you? Let us know!

\section{Repository Citation}

Lewis, Browne C., "Analysing the Extraterritorial Application of the National Environmental Policy Act" (1999). Law Faculty Articles and Essays. 1006.

https://engagedscholarship.csuohio.edu/fac_articles/1006

This Article is brought to you for free and open access by the Faculty Scholarship at EngagedScholarship@CSU. It has been accepted for inclusion in Law Faculty Articles and Essays by an authorized administrator of EngagedScholarship@CSU. For more information, please contact research.services@law.csuohio.edu. 


\section{ANALYSING THE EXTRATERRITORIAL APPLICATION OF THE NATIONAL ENVIRONMENTAL POLICY ACT}

\section{INTRODUCTION}

$\mathbf{I}_{\mathrm{t}}$

t seems that environmental disasters have become the rule rather than the exception in world news today.' Thus, it is not surprising that, in the last few years, people have become increasingly aware of the need to address environmental issues. This increased awareness has been a result of such environmental disasters as the Chernobyl accident, the Valdez oil spill and the devastating oil pollution of the Gulf War. These incidents have caused people to realize that the impact of environmental catastrophes is rarely confined to specific geographic areas and can prove costly to all nations. Environmental degradation usually affects neighbouring countries and, in some instances, the environment on a planetary scale. ${ }^{2}$

The most pressing global environmental problems are considered to be the following: biodiversity, transboundary air pollution, ozone depletion, hazardous waste, deforestation, existing nuclear pollution, and the risk of nuclear accidents. ${ }^{3}$ Recognizing that these problems called for a global solution, the international community has made environmental management one of its top priorities. This acknowledgment has led to the establishment of an increasing number of international organizations and conferences dedicated to the resolution of environmental issues. ${ }^{4}$

Ms. Browne Lewis is a Legal Writing instructor at Hamline University School of Law, J.D. University of Minnesota, LLM in Energy and Environmental Law University of Houston.

I See, e.g. WORLD COMM'N ON ENV'T \& DEV, OUR COMMON FUTURE 1-3 (1987).

2 Jeffrey B. Groy and Gail L. Wurtzler, International Implications of U.S. Environmental Laws, 8-FALL NAT. RESOURCES \& ENV'T 7, 7 (1993).

3 See Joint COMMnique By Industriallzed Nations at Paris Economic Sum. MIT, July 16, 1989, para. 33-50, 28 I.L.M. 1296-98 (1989).

4 One key example of this phenomenon was the Rio Conference on Environment and Development. 
Moreover, in an attempt to address the problem of protecting the earth from environmental; degradation, governments around the world have enacted environmental laws and participated in international treaties and multilateral agreements dealing with environmental issues. 'In keeping with that trends, in 1970, Congress enacted the National Environmental Policy Act (NEPA) $)^{6}$ to "declare a national policy which will encourage productive and enjoyable harmony between man and his environment. ${ }^{11}$

NEPA requires federal agencies to complete an environmental impact statement (EIS) before participating in "major Federal actions significantly affecting the quality of the human environment. ${ }^{18}$ In preparing an EIS, the agency is required to consider the possible adverse effects of the project, methods of mitigating potential damage, and less destructive alternatives. ${ }^{9}$

Although NEPA is often referred to as the Magna Carta of environmental law, federal agencies have tended not to comply with its mandates when their actions extend beyond the United States borders. For example, according to Worldwatch Institute, the United States Air Force and Navy have dumped large quantities of trichloroethylene, a carcinogenic solvent, in Guam. Those actions led to the contamination of the aquifer that supplies drinking water to three-quarters of the island's population. ${ }^{10}$

Elsewhere overseas, various federal agencies support projects such as hydroelectric development, mining, and pesticide spraying without preparing an environmental impact statement to consider the environmental consequences of such actions. ${ }^{11}$ In an attempt to justify their noncompliance

$5 \quad$ Groy, supra at 7

6 National Environmental Policy Act of 1969 (NEPA), 42 U.S.C. $\$ \S 4321-4370 d$ (1988 \& Supp. V 1993).

742 U.S.C. $\$ 4321$ (1988); see also Thomas l. Digan, NEPA And The Presumption Against Extraterritorial Application: The Foreign Policy Exclusion, $11 \mathrm{~J}$. CUNIEMP. HEALTH L. \& POL'Y 165, 165 (1994).

$\$ 42$ U.S.C. \$ 4332(2)(c); see also Susan K. Sclph, Potential Ramifications Of Environmental Defense v. Massey Illustrated By An Evaluation Of United States Agency For International Development Environmental Procedures, 17 WM. \& MARY J. ENVIL. L. 123, 125 (1993).

9 42 U.S.C. $\$ 4332$ (2)(c); see also Joan R. Goldfarb. Extraterritorial Compliance With NEPA Amid The Current Wave Of Environmental Alarm, 18 B.C. ENVTL. AFF. L. REV. 543 (1991).

L.R. Brown at al., State OF THE WORLd 1991 (New York: W.W. Norton \& Co. 1991), 144.

II

See Bruce S. Manheim Jr., NEPA's overseas application, ENvIRoNMENTAL, April 1,1994 at $43-44$. 
with NEPA, the agencies point to the fact that the statute does not specify whether it applies to adverse effects upon foreign environments or to actions taken outside of the United States. ${ }^{12}$

It has long been settled that NEPA applies to federal decisions affecting the environment of the United States, its territories and possessions. ${ }^{13}$ However, there has been and still is substantial disagreement on the issue of whether NEPA applies to federal decisions affecting the environments in foreign nations. Since the passage of NEPA, legal scholars have disagreed as to whether Congress intended for NEPA to apply extraterritorially, ${ }^{14}$

In evaluating the exterritorial application of United States laws, in general, courts have adopted the position that, absent a clear congressional intent to the contrary, a United States law should apply only within the territorial bounds of the United States. ${ }^{15}$ Courts have been reluctant to apply United States laws extraterritorially because they contend that congressional legislation is driven primarily by domestic concerns. ${ }^{16}$ In addition, the courts have concluded that, in most cases, the use of the presumption mitigates the potential conflicts with foreign law. ${ }^{17}$

Courts have also relied upon this presumption when reviewing cases dealing with the extraterritorial application of NEPA. Finding congressional intent on the issue ambiguous, based upon the statutory language, legislative history, and administrative interpretations, courts have explicitly restricted their holdings to the specific facts of the case they are deciding. ${ }^{18}$

12 See, e.g., Schneider, Pentagon Wins Waiver of Environmental Rule, N.Y. Times, Jan. 30, 1991, at A14, col. 1 (late ed.); The statute simply says that "all agencies of the Federal Government shall... include [an EIS] in every recommendation or report on proposals for... major Federal actions significantly affecting the quality of the human environment." 42 U.S.C. $\S 4332(2)(C)$ (emphasis added).

See Enewetak v. Laird, 353 F.Supp. 81 (D. Haw. 1973) (holding that Enewetak was part of the nation encompassed by NEPA).

See, e.g. Robinson, Extraterritorial Environmental Protection Obligations of Foreign Affairs Agencies: The Unfulfilled Mandate of NEPA, 7. N.Y.U. J. INT'L L. \& PoL. 257 (1974); Note, NEPA's Role In Protecting The World Environment, 131 U. PA. L. REV. 353 (1982).

is Foley Bros, Inc. v. Filardo, 336 U.S. 281, 285, 69 S. Ct. 575, 577 (1949).

16 EEOC v. Aramco, 111 S.Ct. 1227, 1230 (1991), quoting Foley Bros., 336 U.S. at 285 .

17 See Foley Bros., 336 U.S. at 284-285.

18 See Andrew A. Smith, The Extraterritorial Application Of The National Environmental Policy Act: Formulating A Reliable Test For Applying NEPA To Federal Agency Actions Abroad, 34 NAT. RESOURCES J. 751, 752 (1994). 
The purpose of this paper is to examine the issue of whether, in light of Congress' actions and the judicial precedents, NEPA should be applied extraterritorially. Section One discusses the extraterritorial application of United States laws in general, the bases supporting the extraterritorial application, and the tests courts have relied upon to determine the appropriateness of extraterritorial application. The section also explores the presumption against extraterritoriality and the logic behind it.

In the second section, the paper addresses the extraterritorial application of NEPA. That sections includes an analysis of the congressional, executive and judicial treatment of the issue.

The third section analyses the pros and cons of applying NEPA extraterritorially. Section four speculates about the future of NEPA's extraterritorial application relying upon proposed actions by Congress and the Executive branch, and upon judicial precedent.

The paper concludes that NEPA should be applied extraterritorially when the United States agencies' actions have environmental impact in foreign countries. That conclusion will be supported by several factors including: (1) since NEPA is a procedural statute, the potential for conflict with foreign laws is minimal; (2) the language of NEPA indicates that Congress was concerned with the global environment; and (3) the reasoning the courts have used to apply antitrust laws extraterritorially is applicable to NEPA.

\section{EXTRATERRITORIAL APPLICATION OF UNITED STATES LAWS}

One of the consequences of living in a global society is that eventually legal disputes arise that require determination of the appropriate law to apply to the situation. Extraterritorial application has traditionally been defined as the exercise by a state of its jurisdiction beyond its boundaries either over the citizens of other countries or over its nationals present in the territory of another state. ${ }^{19}$

Statutory construction first requires an examination of the nature of the statute to determine whether it mandates extraterritorial application. In the absence of explicit language, laws passed by Congress are construed to apply only within the territorial jurisdiction of the United States. ${ }^{20}$ How

19 See Jonathan Turley, "When In Rome": Multinational Misconduct And The Presumption Against Extraterritoriality, 84 NW. U.L. REV. 598, FN 6( 1990).

20 See Sandra W. Maglitozzi, Criminal Law--International Jurisdiction-Federal Child Pornography Statute Applies To Extraterritorial Acts, United States $v$. Thomas, 893 F2d 1066 (9th Cir. 1990), 14 Suffolk TranSNAT'L L.J. 605, 608 
ever, even if a statute does not specifically state that it applies outside the United States territories, extraterritorial application may be inferred by evaluating congressional intent. ${ }^{21}$ Typically, laws of the United States are applied only within the geographic boundaries of the country.

To overcome the presumption and apply the statute beyond the U.S. territory, Congress must have clearly expressed that intent. ${ }^{22}$ Furthermore, international law must be considered when giving extraterritorial application to a statute silent on the extent of its jurisdictional power. ${ }^{23}$ Congress is not bound to comply with international law when enacting legislation, but federal courts usually interpret statutes in a manner that would not violate international law in order to foster international comity.

\subsection{Bases Of Extraterritorial Jurisdiction}

According to the Restatement (Third) of Foreign Relations, there are five situations in which a country has jurisdiction to prescribe laws that have international implications. ${ }^{24}$ Those situations are as follows: (1) when the conduct takes place, wholly or in substantial part, within the country (geographic principle); (2) when the conduct affects the status of persons or things in the country (territorial principle) ${ }^{25}$ (3) when the conduct, although taking place outside the country, affects the country itself (objective territorial principle) ${ }^{26}(4)$ when the conduct involves the state's nationals (nationality principle), ${ }^{27}$ and (5) when the conduct affects the state's na

(1991).

21 Groy, supra at 7; see also United States v. Baker, 609 F2d 134, 136 (5th Cir. 1980) (statute given extraterritorial application if nature of law permits and intended by Congress).

22 Benz v. Compania Naviera Hidalgo, S.A., 353 U.S. 138, 147 (1957).

23 See Chua Han Mow v. United States, 730 F2d 1308, 1311 (9th Cir. 1984) (courts consider international law before giving extraterritorial application).

${ }_{24} \quad$ See United States v. Smith, 680 F.2d 255, 257 (1st Cir. 1982).

25 The "territorial principle" bases jurisdiction on the location of the offense and allows a sovereign complete jurisdiction within its borders.

26 The "objective territorial principle" allows jurisdiction where an offender intentionally causes harmful consequences within a country, although the act itself may have occurred outside the state's territory. See Randall, Universal Jurisdiction Under International Law, 66 TEx. L. REV. 785, 787 N. 8 (1988) (objective territorial principle).

27 The "nationality principle" bases jurisdiction on the nationality of the offender, and allows a nation to assert jurisdiction over its citizens wherever they are. Blackener v. United States, 284 U.S. 421, 436 (1931); se also United States v. King, 552 F.2d 
tional security (protective principle). ${ }^{28} \mathrm{~A}$ variation of the "protective principle" is the "passive personality principle" that bases jurisdiction on the nationality of the victim and allows the country to assert jurisdiction over extraterritorial acts that harm citizens of that country wherever they are located. ${ }^{29}$

In addition, even if none of the five general bases of jurisdiction exists, a state may dictate punishment for offenses of universal concern (universality principle). ${ }^{30}$ The universality principle applies to such offenses as piracy, terrorism, slavery, and war crimes. ${ }^{31}$ The principle is based upon "universal condemnation of those activities and general interest in cooperating to suppress them, as reflected in widely accepted international agreements and resolutions of international organizations." ${ }^{\text {"32 }}$

Even if courts find a basis for extraterritorial jurisdiction, they still may decline to assert jurisdiction. As an additional safeguard against intruding on foreign countries' sovereignty, the federal courts have relied upon a presumption against extraterritoriality.

\subsection{The Presumption Against Extraterritoriality}

It is well established that Congress has the power, under the United States Constitution, to pass legislation that governs conduct occurring outside of the United States territory. ${ }^{33}$ However, the United States Supreme Court has sought to reduce the number of United States laws that are applied extraterritorially by adopting a canon of statutory construction called the

833, 851 (9th Cir. 1976), cert denied, 430 U.S. 966 (1977) (country can apply statue to extraterritorial acts of nationals).

The "protective principle" bases jurisdiction on a national interest and allows a country to assert jurisdiction over criminal acts outside its territory that threaten that country's security. United States v. Smith, 680 F.2d 255, 257 (1st Cir. 1982) (principles by which a sovereign may exercise jurisdiction).

RESTATEMENT (THIRD) OF FOREIGN RELATIONS $§ 402$ (Cum. Supp. 1996).

The "universality principle" bases jurisdiction on physical custody of an offender, and allows states who have such custody to punish, without limit, certain types of offensive conduct. See Id.

Id.; see also Goldfarb, supra at 548.

REstatement (ThIRD) OF Foreign RElations $\$ 404$ comment a (Cum, Supp. 1996). The universality doctrine was historically developed to deal with piracy that interfered with international trade on the high seas.

See EEOC v. Aramco, 111 S.Ct. at 1230 (1991). The Supreme Court stated: "Both parties concede as they must, that Congress has the authority to enforce its laws beyond the territorial boundaries of the United States." 
presumption against extraterritoriality. Under that canon, federal law will not be applied extraterritorially unless Congress clearly expresses an intention to regulate conduct abroad. ${ }^{34}$ The presumption requires the plaintiff to show Congress actually intended for a particular law to apply beyond the United States borders. ${ }^{35}$

The presumption resulted, in part, from an attempt to apply a closely-related canon of construction: that Congress does not usually intend its legislation to violate international law. That canon of construction was first invoked by Chief Justice John Marshall in the Charming Betsy when he stated that "an act of Congress ought never to be construed to violate the law of nations if any other possible construction remains. ${ }^{36}$ In light of that declaration, United States Courts have long held that the application of domestic laws beyond the limits of the enacting state is contrary to certain principles of international conduct and national sovereignty. ${ }^{37}$

For years, the courts used a strict application of the presumption against extraterritoriality to thaw attempts to have United States laws reach conduct outside of its borders. Nonetheless, the courts consistently reiterated that Congress has the authority to extend United States laws beyond its borders to dictate the actions of its citizens. The courts have maintained that in order to exercise that power Congress' intent to do so must be explicitly demonstrated in the statute. ${ }^{38}$

One of the first Supreme Court cases to apply the extraterritoriality presumption was American Banana Co. v. United Fruit Co ${ }^{39}$ In American Banana, the government of Costa Rica seized banana plantations owned by United Fruit Company, an Alabama corporation. The seizure allegedly damaged the plaintiff's business and violated the Sherman Antitrust Act. ${ }^{40}$ The Court held that the defendant's acts were beyond the reach of the Sherman Act because it applied only to those subject to United States legislation. In ruling against the plaintiff, the Court asserted that "the universal rule is that the character of an act as lawful or unlawful must be

See Gary B. Born, A Reappraisal Of The Extraterritorial Reach Of U.S. Law, 24 LAW \& HOL'Y INT'L, BUS. 1,1 (1992).

Turley, supra at 599; see also Dodge, Understanding the Presumption Against Extraterritoriality, 16 BERKELEY J. INT'L L. 85, 101-19(1998).

Murray v. Schooner Charming Betsy, 6 U.S. (2 Cranch) 64, 118 (1804).

See Born, supra at 19-22.

United States v. Mitchell, 553 F.2d 996, $1001-02$ (51h Cir. 1977)

213 U.S. 347 (1909).

American Banana, 213 U.S. at 350. 
determined wholly by the law of the country where the act is done."14

Relying on that rule, the Court concluded that if it were to deem the actions of the Costa Rican government as unlawful under United States antitrust laws, the American court would be interfering with the national sovereignty of Costa Rica. ${ }^{42}$ The Court reasoned in questionable cases, statutes are to be "confined in their operation and effect to the territorial limits" of the enacting legislature's legitimate domain. ${ }^{43}$

After American Banana, the courts treated the presumption as a outright rule against extraterritoriality. This fact was evident when the Supreme Court discussed the presumption against the extraterritorial application of United States laws in Foley Bros. v. Filardo. ${ }^{44}$ In that case, an American citizen alleged that his employer, an American contractor operating in Iran and Iraq under agreement with the United States, was in violation of the Eight Hour law. ${ }^{45}$ The law established a maximum workday and applied to "[e]very contract made to which the United States...is a party..." 46

When deciding the case, the Court noted that (1) Congress intends for United States laws to apply only domestically, unless there is explicit determination included in the statute for application abroad, ${ }^{47}$ and (2) Congress does not intend for legislation to contravene the basic legal principles of other nations. ${ }^{48}$ The Court evaluated the Eight Hour Law in light of those canons.

After reviewing the statute, the Court determined that the "intention...to regulate labour conditions, which are the primary concern of a foreign country, should not be attributed to Congress in the absence of a clearly expressed purpose. ${ }^{49}$ Finding no congressional intent to the contrary, the Court interpreted the statute's language to apply only to private property in the United States. This, in turn, eliminated the argument that the Eight Hour Law was meant to be binding extraterritorially.

The most recent Supreme Court case to discuss the extraterritorial-

Id. 213 U.S. at 356

Id.

American Banana, 213 U.S. at 357.

336 U.S. at 281

40 U.S.C. $\$ \S 324-26$ (repeated 1962).

Id. 40 U.S.C. at $\$ 324$.

Foley Bros., 366 U.S. at 285.

Id. 366 U.S. at 292 (Frankfurter, J., concurring).

Foley Bros., 336 U.S. at 285-86. 
ity principle is EEOC v. Arabian American Oil Co. (Aramco) ${ }^{50}$ In Aramco, the Court reviewed a petition arguing for the extraterritorial application of Title VII of the Civil Rights Act of $1964 .{ }^{\text {s1 }}$ The Civil Rights Act prohibits practices which discriminate on the basis of race, colour, religion, sex, or national origin. ${ }^{52}$ The discriminatory conduct complained of in Aramco was allegedly committed by an American firm operating in Saudi Arabia. ${ }^{53}$

Relying upon the presumption against extraterritoriality, the Court held that the statutory construction and legislative intent were not clear enough to interpret the statute's intent as imposing American employment discrimination laws upon a foreign corporation "operating in foreign commerce..$^{154}$ The Court also expressed concern that United States laws and foreign laws would inevitably clash as a result of the extraterritorial application of the Civil Rights Law. ${ }^{\text {ss }}$

The Court adhered to a strict application of the presumption against extraterritoriality despite (1) the Act's broad language that inciuded all employers engaged in an "industry affecting commerce," of the term commerce as "between a State and any place outside thereof," ${ }^{15}$ ? and (3) the EEOC's position that the Civil Rights Act should be applied extraterritorially. ${ }^{58}$ In response, Congress enacted a bill extending the geographical coverage of the Civil Rights Act of 1991 and the Act now covers United States citizens working in foreign countries. ${ }^{59}$

\subsection{Exceptions To The Presumption Against The Extraterritoriality}

The Aramco decision indicates that the presumption is an irrebuttable presumption against extraterritoriality. ${ }^{60}$ However, in certain types of cases, the courts have used different standards to interpret the extraterritorial

499 U.S. 244 (1991).

42 U.S.C. \$2000e (1988),

Id. 42 U.S.C. at $\$ 2000 \mathrm{e}-2(\mathrm{a})$.

Aramco, 499 U.S. at 255.

Id. 499 U.S. at $255-56$.

ld.

Aramco, 499 U.S. at 248-56; see also 42 U.S.C. at $\$ 2000 \mathrm{e}(\mathrm{g})$.

Id.

Aramco, 499 U.S. at 255.

Civil Rights Act of 1991, Pub.L.No. 102-166, §3(4), 105 Stat. 1071, 1071 (1991) (codified as amended at 42 U.S.C. $\$ 2000 e(f)$. 
scope of statutes. The result has been that courts have interpreted ambiguous market statutes with greater flexibility, allowing extraterritorial application of those that meet certain territorial or conduct requirements. ${ }^{61}$ Consequently, the courts have created several exceptions that can be used to rebut the presumption against extraterritoriality.

One way for the plaintiff to rebut the presumption is to show congressional intent. If there is a clear expression by Congress that the statute is to be applied abroad, the courts will usually defer to that mandate. Congress has exercised its authority to regulate United States actors abroad on several occasions. For example, the Foreign Corrupt Practices Act of 1977 (FCPA) ${ }^{62}$ prohibits bribery of foreign government officials by American citizens subject to the jurisdiction of the Securities and Exchange Commission. $^{63}$

The presumption against extraterritoriality may also be overcome when failure to extend a statute to a foreign country would adversely affect the rights of American nationals or impair the functioning of the United States government. The effects test allows exterritoriality whenever foreign acts have domestic effects. ${ }^{64}$ This test has been applied primarily in cases dealing with market statutes.

The effects test was adopted in United States v. Aluminum Co. Of America (Alcoa). ${ }^{65}$ In that case, the Second Circuit, sitting as the court of last resort by virtue of the Supreme Court's inability to muster a quorum, held that the Sherman Act applied extraterritorially to a Canadian company's participation outside the United States in an international aluminum cartel that allegedly attempted to monopolize aluminum ingot. ${ }^{66}$ The Sherman Act makes illegal any restraint on the trade or commerce "among the several States, or with foreign nations.... ${ }^{1167}$ However, it is silent on the extraterritorial question.

Writing for the Court, Judge Learned Hand adopted an effects test

See, e.g., U.S. v. Sisal Sales Corp, 274 U.S. 268, 276 (1927) (holding that conspiracies furthered by agreements within the United States, but operating in foreign countries, are subject to U.S. laws).

FCPA $\S 101,15$ U.S.C. $\S \S 78 \mathrm{dd}-7811$ (1988).

Id., 15 U.S.C. at $\$ 788 \mathrm{dd}-1$.

See, Turley, supra at 611 (stating that courts have used far-reaching "intended effects" test where defendant intended market cffects).

148 F.2d 416,433 (1945).

Id. $148 \mathrm{~F} .2 \mathrm{~d}$ at 444-45; see also American Tobbaco v. United States, 328 U.S. 781 (1946) (ratifying Alcoa).

15 U.S.C. at $\S \S 1,2(1993)$. 
that permitted the extraterritorial application of the antitrust laws to conduct that had sufficient effects within the United States. ${ }^{68}$ Judge Hand reasoned that conflict-of-laws and state practice permitted a "state [to] impose liability, even upon persons not within its allegiance, for conduct outside its borders that has consequences within its borders which the state reprehends. ${ }^{69}$

Citing the Restatement of Conflict of Laws and three Supreme Court decisions, the Alcoa Court concluded that Congress must have meant to adopt an effects doctrine. ${ }^{70}$ Under that test, the Sherman Act applied to foreign conduct that: (1) was intended to affect U.S. commerce; and (2) actually did affect U.S. commerce. ${ }^{11}$

In the years after 1945, the Supreme Court clearly demonstrated its acceptance of the Alcoa effects doctrine, citing the decision with approval and relying on various formulations of he doctrine. ${ }^{72}$ As a result, Hand's effects test became the standard for many market cases. Relying upon the test, lower courts and federal regulatory agencies applied the antitrust laws extraterritorially to a wide range of international industries, including shipping, watchmaking, synthetic fibres, petroleum, hard metals and newsprint. ${ }^{73}$ in response, a number of the United States' trading partners enacted blocking statutes and other laws designed to prevent the extraterri-

Aloca, 148 F.2d at $443-44$.

Specifically, Judge Hand stated that: "[w|e are not to read general words, such as those in [the Sherman] Act, without regard to the limitations customarily observed by nations upon the exercise of their powers; limitations which generally correspond to those fixed by the "Conflict of Laws." We should not impute to Congress an intent to punish all whom its courts can calch for conduct which has no consequences within the United States. Alcoa, 148 F.2d at 443.

Judge Hand cited $\S 65$ of the Restatement OF CONFLICr OF LAwS which recognized the effects doctrine.

"Alcoa, 148 F.2d at 443-44. The Court held that, once a plaintiff established that the cefendant intended to affect U.S. commerce, then the burden of proving that no such effect actually occurred shifts to the defendant. $I d$. at 444 .

See, e.g., Steele v. Bulova Watch Co., 344 U.S. 280, 288 n. 16 (1952); Zenith Radio Corp. v. Hazeltine Research Corp., 395 U.S. 100, 113 n. 8 (1969).

See, e.g., In re Grand Jury Investigation of the Shipping Indus., 186 F. Supp. 298 (D.D.C. 1960); United States v. Watchmakers of Switz. Info. Ctr., 133 F. Supp. 40 (S.D. N.Y. 1955); United States v. Imperial Chem. Indus., 105 F. Supp. 215 (S.D. N.Y. 1952); In re Investigation of World Arrangements with Relation to the Prod, Transp., Ref. \& Distrib. Of Petroleum, 13 F.R.D. 280 (D.D.C. 1952); United States v. General Elec. Co, 80 F. Supp. 989 (S.D. N.Y. 1948); In re Grand Jury Subpoenas Duces Tecum Addressed to Can. Int'l Paper Co, 72 F.Supp. 1013 (S.D. N.Y. 1947). 
torial application of the United States antitrust and other laws. ${ }^{74}$

United States courts and regulatory authorities sought to moderate the extraterritorial reach of the Sherman Act and other federal antitrust laws in order to alleviate the protests from other countries. This was accomplished by adding a reasonableness requirement to the effects test. Thus, the courts repeatedly held that, even if the country has a basis for jurisdiction, the exercise of extraterritorial jurisdiction has to be reasonable. ${ }^{75}$

This reasonableness requirement calls for consideration of a variety of factors, including the nature of the activity, the extent of each country's interest, the location of the relevant conduct, the effects of the conduct, the parties' nationalities, and the extent of any conflict with foreign law and other factors. ${ }^{76}$ The end result was the development of an alternative conflicts test.

The use of that test is illustrated by Timberlane Lumber Co. v. Bank of America (Timberlane I).$^{77}$ In Timberlane I, the Ninth Circuit confronted an alleged conspiracy to monopolize the milling of Honduran lumber. The Court found that the plaintiffs had a cognizable claim under the Sherman Act. However, the Court ultimately dismissed the complaint on the grounds that the antitrust laws did not apply to the defendants' conduct. ${ }^{78}$

The Court reasoned that to decide whether U.S. anti-trust laws apply to conduct abroad, a three-part test must be applied. ${ }^{79}$ The first two prongs of the test closely tracked the Alcoa effects test; taken together, they require a showing that foreign conduct had a "direct and substantial anticompetitive effect" on U.S. commerce. ${ }^{80}$ The third prong of the test

74 These laws often take the form of blocking or non-disclosure statutes that forbid litigants from providing evidence for use in U.S. or other foreign judicial proceedings.

75 See RESTATEMENT (THIRD)OF FOREIGN RELATIONS $§ 403$ (1).

76 See Joseph E. Fortenberty, Jurisdiction Over Extraterritorial Antitrust Violations. 32 OHO ST. L. J. 519, 534-36 (1971); see also RESTATEMENT (THIRD) OF FOREIGN RELATIONS $\$ 403(2)$.

$n \quad 549 \mathrm{~F} .2 \mathrm{~d} 597$ (9th Cir. 1977).

78 Timberlane II, 749 F.2d 1378, 1386 (9th Cir. 1984), cert. denied 105 S. Ct. 3514 (1985)..

7979. Under Timberlane /, a court must make three discrete inquires: 1) Does the alleged restraint affect, or was it intended to affect, the foreign commerce of the United States?; 2) Is it of such a type and magnitude so as to be cognizable as a violation of the Sherman Act?; and 3) As a matter of international comity and fairness, should the extraterritorial jurisdiction of the United States be asserted to cover it? $549 \mathrm{~F} .2 \mathrm{~d}$ at 615 . 
implemented a rule of reason derived from its perceptions of contemporary principles of international law and comity. ${ }^{81}$ Based upon the rule of reason, in order to get the court to apply a U.S. antitrust law extraterritorially, the plaintiff must show that "the interests of, and links to, the United States...are sufficiently strong, vis-a-vis those of other nations, to justify an assertion of extraterritorial authority: $: 82$ The Court rested its rule of reason evaluation on conflict of laws analysis and what it called the doctrine of international comity. ${ }^{83}$

The extraterritoriality presumption may be rebutted when the statute regulates conduct which occurs in the United States, but the primary effects are felt in foreign nations. The conduct test is closely related to the effects test. Under the conduct test, a federal court has subject matter jurisdiction if (1) the defendant's actions in the United States were more than "merely preparatory" to a securities fraud conducted elsewhere, and (2) those actions or culpable failures to act within the United States "directly caused" the claimed losses. ${ }^{84}$

\section{EXTRATERRITORIAL APPLICATION OF NEPA}

In enacting NEPA, Congress responded to growing concern over the environmental impacts of government actions. Congress wanted to ensure that federal agencies considered environmental effects when planning projects. ${ }^{85}$ In light of that desire, NEPA governs the activities of all federal agencies and declares the environmental policy of the nation. ${ }^{186}$

NEPA does set forth significant goals for the Nation, but its man-

81 Timberlane l, $549 \mathrm{~F} .2 \mathrm{~d}$ at 613.

s2 Id, 549 F.2d at 613. Timberlane $I$ sets forth a seven-factor, ad-hoc interest-balancing test to determine when extraterritorial antitrust jurisdiction would be permitted under the rule of reason.

83 Timberlane I, 549 F.2d at 611-14. The Court said, "We believe that the field of conflict of laws presents the proper approach." $/ d .549$ F.2d at 613.

84 Itobaltd v. LEP Group PLC, 54 F.3d 118, 122 (2d Cir. 1995), cert. denied 116 S.Ct. 702 (1996); see also North South Finance Corp. v. Al-Turki, 100 F.3d 1046, 1050 (2nd Cir. 1996).

s Gary M. Emsdorff, The Agency For International Development And NEPA: $A$ Duty Unfulfilled, 67 WASH. L. REV. 133, 133 (1992). 
date to the agencies is essentially procedural. ${ }^{87}$ It requires agencies to prepare an environmental assessment (EA) to determine the level of impact a proposed project will have on the environment. An EA includes a discussion of the need for the proposed action, altematives to the proposed action, and the environmental impacts of the proposed action and its alternatives. The resulting document serves as the basis for either a Finding of No Significant Impact (FONSI), requiring further review, or a decision to prepare an environmental impact statement (EIS) ${ }^{88}$ Agencies must prepare an EIS for all proposed actions that will significantly effect the human environment. ${ }^{89}$

Controversy over the extraterritorial application of NEPA began shortly after the statute was enacted. ${ }^{90}$ Federal agencies employed a purely domestic application of NEPA, while environmentalists argued for an extraterritorial application of NEPA. The debate between the two sides has continued because it is unclear from reading the statute whether NEPA was intended to apply abroad.

As with any congressional statute, the first step in interpreting NEPA involves searching in the statutory language, and, if the plain meaning is still unclear, in the legislative history for expressions of legislative intent. It is also helpful to review the interpretations of the administrative agencies responsible for regulating NEPA's application, the executive branch, and the courts. ${ }^{91}$

NEPA lacks the clear statement of congressional intention required to apply a statute outside of the United States. Moreover, NEPA's statutory language, legislative history, and administrative and executive interpretations are considered largely inconclusive on the issue of extraterritorial application. ${ }^{92}$

87 Vermont Yankee Nuclear Power Corp. v. NRDC, 435 U.S. 519, 558 (1978); see also Willian M. Cohen, Practical Considerations In Litigating Cases Under The National Environmental Policy Act, CA37 ALl-ABA 449, 449 (1996).

88 Council on Environmental Quality Guidelines, 40 C.F.R. $\$ 1508.11$ (1992).

8942 U.S.C. $\$ 4332(2)(C)$.

See Silvia M. Riechel, Note, Government Hypocrisy And The Extraterritorial Application OfNEPA, 26 CASE W. RES. J. INT'L L.115, 126 (1994).

91 Goldfarb, supra at 553.

92 George H. Keller, Note, Greenpeace v. Stone: The Comprehensive Environmental Impact Statement and the Extraterritorial Reach Of NEPA, 14 U. HAW. L. REV. $751,768-71$ (1992) (noting how vagueness of language, legislative history, and interpretive regulations of NEPA lead to difficulties in determining congressional intent regarding extraterritorial application); Comment, NEPA's Role In Protecting The World Environment, 131 U. PA. L. REV. 353, 360-64 (1982) (commenting on 


\subsection{Congressional Interpretation}

\subsubsection{Statutory Language}

There is no provision in NEPA expressly addressing the application of NEPA outside the United States. The statutory language of NEPA does not help to resolve the issue of the statute' $s$ extraterritorial reach. ${ }^{93}$ The language of various sections voices a concern for "future generations of Americans" and "our national heritage," which tends to imply a domestic application. On the other hand, the language in other sections refers to the "human environment" and "man's environment," suggesting a global application." 94

The statute's stated purpose is " $[t]$ o declare a national policy which will encourage productive and enjoyable harmony between man and his environment; to promote efforts which will prevent or eliminate damage to the environment and biosphere and stimulate the health and welfare of man; [and] to enrich the understanding of the ecological systems and natural resources important to the Nation....."195

Section 101 of NEPA is the congressional declaration of the national environmental policy. Many of the policy provisions refer either to the United States or to the world. Some provisions are domestic in breadth. For instance, one purpose of the statute is to "declare a national policy....to enrich the understanding of the ecological systems and natural resources important to the Nation." ${ }^{196}$ Another policy is to ensure that nature can "fulfill the social, economic, and other requirements of present and future generations of Americans." ${ }^{197}$ Finally, Congress declares a policy of using all practicable means "consistent with other essential considerations of national policy" to "assure for all Americans safe ... surroundings," and to "preserve important ... aspects of our national heritage." "98

Many other provisions, in contrast, imply concern for global environmental problems. The purposes of the statute include such universal objectives as to "encourage productive and enjoyable harmony between ...

NEPA's inconclusive legislative history).

93.Karen A. Klick, The Extraterritorial Reach Of NEPA 's EIS Requirement After Environmental Defense Fund v. Massey, 44 AM.U. L. REV. 291, 297 (1994).

42 U.S.C. at $\S \S 4321,4322$.

42 U.S.C. at $\$ 4321$.

42 U.S.C. at $\$ 4321$ (emphasis added).

ld. at $\S 4331$ (a) (emphasis added).

Id. at $\S 4331$ (b) (emphasis added). 
man and ... his environment" and to stimulate the health and welfare of ... man. ${ }^{99}$ The policies also include a recognition of the "impact of ... man's activity on ... the natural environment," and of the "importance of restoring and maintaining environmental quality to the overall welfare and development of ... man. ${ }^{100}$

In the EIS provision, section 102(2)(C), Congress called on "all agencies of the Federal Government" to prepare an EIS for "major Federal actions significantly affecting the quality of the human environment."101 Even though there are several federal agencies whose activities are largely international, no language in the statute provides that the EIS requirement does not apply to the international activities of those agencies.

This section contains many references to global concerns. For example, section $102(2)(F)$ requires all federal agencies to "recognize the worldwide and long-range character of environmental problems and, where consistent with the foreign policy of the United States, lend appropriate support to initiatives, resolutions, and programs designed to maximize international cooperation in anticipating and preventing a decline in the quality of mankind's world environment. ${ }^{102}$

As the above discussion indicates, the statutory language does not answer the question whether or not Congress intended NEPA to be applied extraterritorially. Consequently, in order to ascertain the congressional intent, it is necessary to look at the statute's legislative history.

\subsubsection{Legislative History}

Unfortunately, the legislative history is equally inconclusive on the issue of NEPA's extraterritoriality. Congress did not engage in lengthy debate when it drafted and enacted NEPA. ${ }^{103}$ The debates that were held focussed on domestic application of the statute, without referring to international reach. As a result, it is difficult to determine from the legislative history how broadly Congress intended the statute to be applied.

A joint House-Senate Colloquium for discussion of environmental

42 U.S.C. at $\$ 4321$ (emphasis added).

Id. at $\S 4331$ (a) (emphasis added).

42 U.S.C. at $\S 4332(2)(C)$.

Id. at $\S 4332(2)(\mathrm{F})$ (emphasis added).

Goldfarb, supra at 556. 
policy conceived NEPA. ${ }^{104}$ A congressional White Paper on a National Policy for the Environment summarized the debates and conclusions of the Colloquium. ${ }^{105}$ The Senate and the House then independently reported their own versions of the statute and appointed members to participate in a conference to draft a compromise bill, which was enacted as NEPA.

The White Paper included a section recognizing the importance of considering environmental impacts of international projects. ${ }^{106}$ In addition, the White Paper acknowledged the basic principle that everything in the world environment is linked interactively. ${ }^{107}$ The White Paper also stipulated that, because Congress cannot predict future scientific discoveries or societal values, NEPA should be drafted as to adapt to any future findings. ${ }^{108}$

Some statements and reports pertaining to NEPA secm to indicate that Congress assumed the statute would be applied extraterritorially. For example, the House Report stated that assessing international environmental impacts is implicit in the statue. ${ }^{109}$ After the compromise conference, Senator Jackson remarked that he believed the mandate of NEPA would not cause ideology, security, or balance of power conflicts with foreign nations. ${ }^{10}$ This statement may be read to imply that the senator expected the statute to be applied in international situations. However, the assumptions of a single senator is not enough legislative history to support a determination that NEPA was intended to apply to activities outside of the United States border.

Jn. Joint House-Senate Colloguium to Discuss a National Policy for the Environment: hearing before the Comm. on Interior and Insular Affairs, U.S. Senate, and the Committee on Science and Astronautics, U.S. House of Representatives, 90th Cong., 2d Sess. 87-127 (1968).

105 Congressional White Paper on a National Policy for the Environment, 115 Cong. Rec. 29,078 (1969).

106 The White Paper describes "the urgent necessity of taking into account major environmental influences of forcign economic assistance and other international developments." See White Paper, supra at 29,079.

"Organic nature is such a complex, dynamic, and interacting, balanced and intertelated system that change in one component cntails change in the rest of the system." Id.

White Paper, supra at $29,079$.

H. Rep. No. 378, 91 st Cong., Ist Sess. 9, reprinted in 1969 U.S. Code Cong. \& Admin. News 2751, 2759.

Cong. Rec. S40, 417 (daily ed. Dec. 20, 1969) (statement of Sen. Jackson), quoted in Enewetak, 353 F. Supp at 818. 


\subsection{Executive Interpretation}

The agencies primarily responsible for foreign policy and NEPA are the Department of State and the Council on Environmental Quajity (CEQ) respectively. The agencies have both articulated separate interpretations of the exterritorial application of NEPA.

\subsubsection{State Department Policy}

The State Department has continued to maintain that foreign policy considerations may preclude the extraterritorial application of NEPA. ${ }^{\prime \prime \prime}$ The State Department has expressed concerns that imposing a domestic law, such as NEPA, on projects initiated by other sovereigns would violate traditional principles of international comity and fairness and could place too much stress on foreign relations. Hence, the State Department has promulgated provisions in the Code of Federal Regulations exempting specific activities from NEPA compliance, such as participation in, or contribution to, international organizations the United States cannot control. ${ }^{112}$

\subsubsection{Council On Environmental Quality (CEQ)}

The CEQ was created by Title II of NEPA. ${ }^{113}$ It is responsible for oversecing the achievement of goals set forth in our national environmental policy, including gathering information and advising the President on environmental issues. ${ }^{114}$ In 1977 , President Carter amended the executive order directing CEQ to issue procedures on implementation of the NEPA process to require CEQ to issue regulations that would be binding on all federal agencies. ${ }^{115}$

The CEQ consistently asserted that NEPA applies extraterritorially. In 1978, the CEQ issued a memorandum and draft regulations for applying

11 See Department of State Regulations for Implementing the National Finvironmental Policy Act, 22 C.F.R. $\$ 161.7$ (d) (1995).

112 Id.

11342 U.S.C. $\$ 4344(3)$.

11442 U.S.C. $\$ 4344$. Section 204 of NEPA details the duties and functions of the CEQ. Id.

it Dinah Bear, The National Environmental Policy Act: Its Origins And Evolutions, 10-Fall Nat. Resources \& Env't 3, 70 (1995). 
NEPA extraterritorially. ${ }^{16}$ The guidelines specified that, for projects directly affecting the environment of either the United States, the global commons, or Antarctica, agencies must comply with NEPA ${ }^{117}$ For projects affecting only the environment in foreign country, agencies would have to complete a foreign environmental statement, which would be a shorter, less detailed version of an EIS. The foreign environmental statement would require only three elements: a statement of purpose and need, a discussion of alternatives to the proposed action, and a succinct description of the area to be affected. ${ }^{118}$

Pressure from the State Department forced CEQ to retreat from its position and withdraw the proposed regulations. ${ }^{119}$ Current CEQ regulations do not address NEPA's application to agency actions occurring outside of the United States. Thus, the agency's current silent on the issue merely adds to the confusion.

\subsubsection{Executive Order 12,114}

Executive Order 12,114 puts another spin on NEPA's extraterritorial application. Facing an administrative stalemate over NEPA's international reach, President Jimmy Carter issued the executive order in 1979 to clarify the issue. ${ }^{120}$ Executive Order 12,114 stipulates that NEPA applies extraterritorially if the action (1) affects a foreign country that is not involved in the actions, (2) affects the global commons, (3) exposes a foreign country to toxic or radioactive emissions, or (4) affects resources of global concern. ${ }^{121}$ The Executive Order also attempts to reconcile the concerns of the State Department and of the CEQ by exempting from NEPA compliance those activities that worried the State Department. This exemption includes all intelligence activities, arm transfers, export licenses, votes in international organizations, and emergency relief action. ${ }^{122}$ The

116 Council on Environmental Quality Memorandurm to Agency Hcads on Overseas Application of NEPA Regulations (I 978), reprinted in 8 Env't Rep. (BNA) 1493 (1978); see also Council on Environmental Quality Draft Regulations on Applying NEPA to Significant Foreign Environmental Effects (I 978), reprinted in 8 Env't Rep (BNA) 1495 (1978).

117 Id.

$118 \quad$ Id

119 Smith, supra, at 754.

120 Exec. Order No. 12,114, 44 Fed. Reg. 1957 (1979), reprinted in 42 U. S.C. $\S 4321$ (1988).

12] Id § 2-3, 44 Fed. Reg. at 1957-58, reprinted in 42 U.S.C. § 4321, at 515.

122 Order, at $\S 2-5($ a), 44 Fed. Reg. at 1959 , reprinted in 42 U.S. C. $\S 4321$ at 516. 
order also allows agencies to modify the EIS requirements in consideration of international commercial competition, national security, difficulty of obtaining information, and inability of the agency to affect the decision. ${ }^{123}$

The Order purportedly "represents the United States government's exclusive and complete determination of the procedural and other actions to be taken by agencies to further the purpose of (NEPA] with respect to the environment outside the United States . ..." ${ }^{124}$ Although the Order appears to recognize the importance of applying NEPA extraterritorially, exceptions and limitations render its mandates relatively ineffective compared to the NEPA requirements.

The Order is ineffective in several respects. First, it is riddled with specific exceptions, ${ }^{125}$ and numerous opportunities for discretionary exemptions ${ }^{126}$ and modifications. ${ }^{127}$ Second, enforcement capabilities are weak because the Order only sets internal agency procedures, and explicitly cannot be enforced through a private cause of action. ${ }^{128}$ Third, the source of the order's authority is questionable. Because the Order was issued based on authority independent of NEPA, and was not meant to invalidate any existing regulations, ${ }^{129}$ it actually did very little to clarify the scope of NEPA's extraterritorial application.

\subsection{Judicial Interpretation}

NEPA case law has not clearly answered the question of whether NEPA applies to federal agency actions occurring outside of the United States. Several courts have assumed that NEPA applies abroad, but have declined to directly rule on the issue largely at the request of the government, which in each case agreed to prepare an EIS for its foreign action. In decisions rejecting NEPA's application to foreign projects, the courts explicitly restricted their holdings to the specific circumstances of the cases, thereby leaving open the possibility that NEPA might apply to such actions absent

Id.

Order, at \$1-1, 44 Fed. Reg. 1957, reprinted in 42 U.S.C. $\$ 4321$, at 515.

See Order at $\S 2-5(\mathrm{a}), 44 \mathrm{Fed}$. Reg. at 1959, reprinted in 42 U.S.C. $\S 4321$ at 516. (listing numerous exempted actions).

Id. at $\$ 2-5(\mathrm{c}), 44$ Fed. Reg. at 1959, reprinted in 42 U.S.C. $\S 4321$ at 516.

Order, at $\S 2-5$ (b), 44 Fed. Keg. at 1959 , reprinted in 42 U. S.C. $\$ 4321$ at 516.

ld. at $\S 3-1,44$ Fed. Reg. at 1960, reprinted in 42 U. S.C. $\S 4321$ at 517 .

Order, at $\S \mathrm{I}-\mathrm{I}, 44$ Fed. Reg. at 1957, reprinted in 42 U.S.C. $\S 4321$ at 515. 
overriding foreign policy considerations. ${ }^{130}$

\subsubsection{People of Enewetak v. Laird}

In dealing with the extraterritorial application of NEPA, courts were first confronted with the issue of whether NEPA applied to U.S. trust territories. In People of Enewetak v. Laid, ${ }^{131}$ the District Court of Hawaii held that NEPA applied to a federal project to test explosives on a U.S. island territory. ${ }^{132}$ The Court noted that NEPA's terminology included the broader term "nation" where "United States" would have served more effectively if Congress had intended to limit the jurisdiction of the statute. ${ }^{133}$

\subsubsection{Sierra Club v. Adams and NORML v. U.S. Department of State}

In the first cases addressing NEPA's extraterritorial application to non-U.S. territories, courts typically summarily assumed that NEPA applied to federal action with international implications. Those decisions were based on the statute's expansive language, the degree of United States federal involvement in the action, and the domestic effects of the action.

For example, in Sierra Clubv. Adams, ${ }^{134}$ the court assumed without deciding that NEPA applied to a U.S.-sponsored highway project in Panama and Columbia because a cattle epidemic presented a health risk to U.S. citizens assisting in the construction of the highway. ${ }^{135}$ In National Organization for the Reform of Marijuana Laws (NORML) v. U.S. Department of State, ${ }^{136}$ the Court also presumed, without discussion, that NEPA applied to U.S. involvement in a herbicide program to eradicate marijuana and poppy plants in Mexico ${ }^{137}$ In reaching its decision, the Court reasoned that NEPA applied to the U.S. portion of the program because of the adverse side-effects that American users were experiencing. ${ }^{138}$ Thus, the decision

Kourtney Twenhafel, Freeport McMoran's Midas Touch: Testing The Application Of The National Environmental Policy Act To Federal Agency Actions Governing Multinational Corporations, 4 TUL. J. INT'L \& COMP. L. 303, 319-23 (1996).

353 F. Supp. at 811.

Enewetak, 353 F.Supp at 819.

Id. 353 F.Supp at 816 .

578 F.2d 389 (D.C. Cir. 1978).

Sierra Club, 578 F.2d at 394.95.

452 F.Supp. 1226 (D.D.C. 1978).

NORML, 452 F.Supp. at 1232-33.

Id 452 F. Supp at 1232. 
was the result of applying an effects test. The precedent may be used to argue that federal actions in foreign countries that have an effect on American citizens may be governed by the procedural mandates of NEPA.

\subsubsection{Natural Resources Defence Council Inc. v. Nuclear Regulatory Commission}

In response to some NEPA challenges to federal agency action, the courts have adhered to the presumption against extraterritoriality and ruled against the plaintiffs. However, the courts limited their decisions in those cases to the specific facts involved. Among the first decisions denying NEPA's exterritorial application was that of Natural Resources Defence Council Inc. $v$. Nuclear Regulatory Commission. ${ }^{139}$ The issuc in that case was whether the decision to issue an export license triggered the NEPA requirement of an EIS when the only significant environmental impacts would be felt in the importing country. ${ }^{140}$ The Court relied on foreign policy grounds to support its holding that NEPA did not apply to the exportation of the nuclear reactor to the Phillippines. The court stated that NEPA focuses on "cooperation, not unilateral action, in a manner consistent with our foreign policy," and that the EIS requirement for nuclear exports would be "incongruous in the nuclear exports/nuclear non-proliferation context."141 However, the Court did not preclude the extraterritorial application of NEPA in all situations, but only with respect to the facts before it.

\subsubsection{Greenpeace U.S.A. v. Stone}

In 1990, in Greenpeace U.S.A. v. Stone, ${ }^{142}$ the District Court for Hawaii also refused to apply NEPA outside of U.S. borders. ${ }^{143}$ The following facts were involved in that case: Greenpeace claimed that the Army failed to comply with NEPA because it did not prepare a comprehensive EIS before transporting chemical munitions from the Federal Republic of Germany to the U.S. territory of Johnston Atoll in the central Pacific Ocean. ${ }^{14}$ The Court stated that it believed that Congress probably wanted federal agencies to consider the global impact of domestic actions and "may have intended

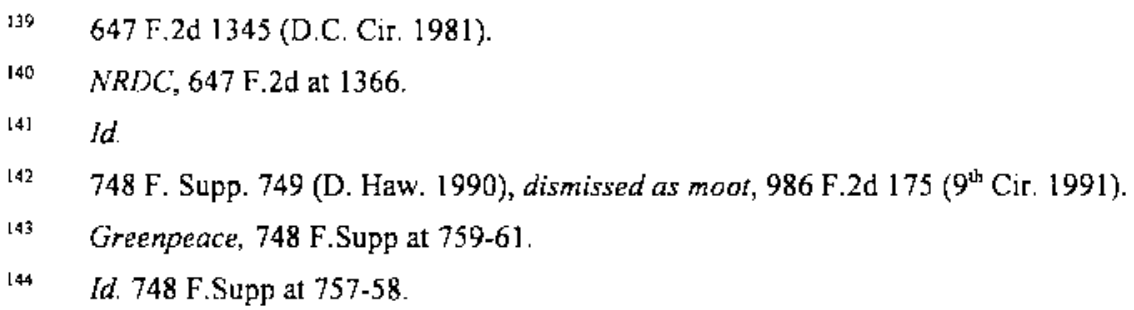


under certain circumstances for NEPA to apply extraterritorially."145 Nonetheless, the court held that the application of NEPA within another country's borders would cause foreign policy conflicts and interfere with the decision making functions of the United States and foreign sovereigns. Again, however, the court limited its decision to the facts of the particular case. By the time the case was appealed to the Ninth Circuit, the transport had taken place and the issue was moot. ${ }^{146}$

\subsubsection{Environmental Defence Fund, Inc. v. Massey}

Another case involving the extraterritorial application of NEPA concerned Antarctica. In that case, the National Science Foundation (NSF) operated the McMurdo Station research facility in Antarctica. ${ }^{147}$ Food wastes generated at the facility were burned in an open landfill. In early 1991, after deciding to improve its environmental practices in Antarctica, the NSF halted the burning of the waste. The wastes were stored from February to July 1991, when a delay in the planned delivery of a state-of-the-art incinerator to McMurdo Station forced the NSF to resume burning in an "interim incinerator." 148

The Environmental Defence Fund brought an action seeking injunctive relief, aileging that the NSF violated NEPA because it failed to prepare an environmental impact statement before going forward with its plans to incinerate food wastes. The district court in Environmental Defence Fund, Inc. v. Massey ${ }^{149}$ dismissed the case for lack of subject matter jurisdiction. The Court found that the statute did not contain the requisite "clear expression of legislative intent through a plain statement of extraterritorial statutory effect." ${ }^{150}$ However, in a case of first impression, ${ }^{151}$ a three-member panel of the D.C. CIRCUIT Court of Appeals concluded

Greenpeace, 748 F.Supp. at 759.

Greenpeace, 924 F.2d 175 (9th Cir. 1991).

See George Kahale III and David A. Wirth, Environmental--Extraterritorial Effects Of Activities of Federal Agencies-- Waste Disposal In Antarctica-National Environmental Policy Act Of 1969; Environmental Defense Fund. Inc. v. Massey, 986 E 2d 528 (D. C. Cir. 1993), 87 AM. J. INT'L L. 626 (1993).

Environmental Defense Fund, Inc. v. Massey, 986 F.2d 528, 530 (D.C.Cir. 1993).

772 F. Supp. 1296 (D.D.C. 1991 ).

Massey, 772 F.Supp at 1297, citing E.E.O.C. v. Arabian American Oil Co., 499 U.S. 244 (199l).

The D.C. Circuit Court of Appeals once before considered the application of NEPA overseas, but did not decide the issue. Sierra, 578 F.2d at 392. 
otherwise. $^{152}$

Based in large measure on the uniqueness of Antarctica as a continent without a sovereign and the area's consequent treatment as a "global common," 153 the Circuit Court found that since NEPA controls government decision making and imposes no substantive requirements which could be interpreted to govem conduct abroad, ${ }^{154}$ and since the federal decision making process which resulted in the use of an "interim incinerator" at McMurdo Station took place almost exclusively within that country, ${ }^{155}$ the presumption against extraterritoriality did not apply. ${ }^{156}$ Nevertheless, the Court was careful to note that its decision did not extend to the possible application of NEPA "to actions in a case involving an actual foreign sovereign or how other U.S. statutes might apply to Antarctica." ${ }^{157}$ Indeed, the Court made a point of limiting the application of its decision to the facts of the case before it. ${ }^{158}$ The administration sought neither rehearing nor appeal of the court's decision, implicitly accepting the applicability of NEPA to activities in Antarctica. ${ }^{159}$

\subsubsection{NEPA Coalition of Japan v. Aspin}

More recently, in NEPA Coalition of Japan $v$. Aspin, ${ }^{160}$ plaintiffs brought an action against the Secretary of Defence, asserting that NEPA required the Department of Defence (DOD) to prepare EISs for certain U.S. military installations in Japan. ${ }^{161}$ Citing the Circuit Court's decision in Massey, the NEPA Coalition court determined "that the legal status of the United States bases in Japan [was] not analogous to the status of American research

Massey, 986 F.2d at 528 .

Id. 986 F.2d at 529, citing Beattie $v$, United States, 756 F.2d 9I, 99 (D.C.Cir. 1984).

Massey, 986 F.2d at 533 .

Id. 986 F.2d at 532 .

Massey. 986 F.2d at 533 .

Id. $986 \mathrm{~F} .2 \mathrm{~d}$ at 536 .

ld.

See Lieutenant Colonel Richard A. Phelps, Environmental Law For Overseas Installation, 40 A.F.L. REV. 49, 50-51 (1996).

937 F. Supp. 466 (D.D.C. 1993).

See John F. Breggs, Combating Biospheric Degradation: International Environmental Impact Assessment And The Transboundary Pollufion Dilemma, 6 FORDHAM ENVTL. L.J. 379, 395-86 (1995). 
stations in Antarctica." ${ }^{162}$ The Court noted that DOD's operations in Japan were governed pursuant to the Treaty of Mutual Cooperation and Security of $1960,{ }^{163}$ and the Status of Forces Agreement ("SOFA"), ${ }^{164}$ which constituted, in the view of the Court, "complex and long standing treaty arrangements." 165

The court indicated that requiring the DOD to prepare EISs would encroach upon the treaty relationship, because it would necessarily require the DOD to collect environmental data from surrounding residential and industrial complexes (as well as Japanese military activities], thereby interfering with Japanese sovereignty. ${ }^{166}$ Accordingly, the Court concluded that the presumption against extraterritoriality "particularly applies" in instances where "there are clear foreign policy and treaty concerns involving a security relationship between the United States and a sovereign power."167

\subsubsection{Mayaguezanos Por La Salud Y El Ambiente, et. al. v. United States}

The most recent case dealing with the application of NEPA outside of the United States was decided in December of 1999. In that case, Mayaguezanos Por La Salud Y El Ambiente, et. al. v. United States ${ }^{168}$, the Pacific Swan, a British-flag freighter carrying a cargo of vitrified high-level nuclear waste, wanted to pass through the Mona Passage, a stretch of seas between the islands of Puerto Rico and Hispaniola. In response, a group of fishermen and environmental organizations from western Puerto Rico brought an action for an injunction to stop the shipment until the United States filed an EIS in accordance with NEPA. As a part of the shipment, uranium from the United States was to be sent to Japan to fuel nuclear reactors, ${ }^{169}$

Before the Court, the plaintiffs argued that there was major federal action because the United States was required to play some role in the

NEPA Coalition, $837 \mathrm{~F}$. Supp. at 467.

Treaty of Mutual Cooperation and Security Between the United States of America and Japan, Jan. 19, 1960, U.S.-Japan, 1 I U.S.T. 1633-35.

Administrative Agreement Under Article IlI of the Security Treaty Between the United States of America and Japan, Feb. 28, 1952, U.S.-Japan, 3 U.S.T. 3342- 62.

NEPA Coalifion, 837 F. Supp. at 467.

Id. 837 F. Supp, at 467 n.5.

NEPA Coalition $837 \mathrm{~F}$. Supp. at 468.

198 F.3d 291 (1" Cir 1999).

Mayaguezanos, 198 F.3d at 299. 
transport of the waste under various international agreements and customary international law. The United States countered by stating that the shipment of waste was the "action" and that action was not being carried out by a federal agency but by private parties. ${ }^{170}$

The Court concluded that since the plaintiffs' claims did not pass the "major federal action" tests, it did not have to reach the issue of whether or not NEPA should be applied extraterritorially. ${ }^{171}$ However, in dictum, the Court stated that it was sceptical that NEPA's "major federal action" requirement would work in the same fashion in the domestic and the international contexts. Moreover, the Court also stated that few courts have decided whether NEPA applies extraterritorially. ${ }^{172}$

\section{ANALYSIS OF THE Pros AND CONS OF NEPA EXTRATERRITORIAL APPLICATION}

This section explores some of the arguments for and against applying NEPA extraterritorially. Since environmental pollution does not recognize political boundaries, it makes sense to apply NEPA extraterritorially. Moreover, NEPA is among the most effective ways the United States government can monitor and control its impact on the global environment. If NEPA is applied extraterritorially on a consistent basis to the international activities of federal agencies, it will benefit the United States. ${ }^{173}$

For example, one beneficial aspect of the statute's extraterritorial application is that compliance with NEPA's requirements abroad would help protect the United States from the creation of, and liability for, international disasters. ${ }^{174}$ That compliance would also enable the United States to live up to principle 21 of The Stockholm Declaration on the Human Environment which requires countries to avoid causing environmental damage to neighbouring countries. ${ }^{175}$

A second benefit of the extraterritorial application of NEPA is that

\footnotetext{
170 Id. $198 \mathrm{~F} .3 \mathrm{~d}$ at 300.

171 Id. $198 \mathrm{~F} .3 \mathrm{~d}$ at 301.

$172 \quad$ Id. $198 \mathrm{~F} .3 \mathrm{~d}$. at $30 \mathrm{~L}$, fn 9 .

17 See Klick, supra at 318.

174 See Turley, supra at 640-42 (noting serious environmental impacts of transnational activities).

175 Report of the United Nations Conference on the Human Environment, at 3, 5, U.N. Doc. A/CONF.48/14/Rev. 1 (1973) (states have responsibility to ensure that activities within their jurisdiction or control do not cause damage to the environment of other states or areas beyond the limits of national jurisdiction).
} 
the United States' reputation will be improved by taking a leadership role in protection of the global environment. ${ }^{176}$ This may also encourage developing countries to create their own environmental protection programs. In addition, developing countries often lack the ability to adequately determine the environmental consequences of a proposed action, and rely heavily on United States decision-makers to make well-informed decisions that include consideration of environmental factors. Further, applying NEPA to international projects would be politically wise because it would send a signal to developing nations that the United States recognizes the environmental concerns of its projects to other nations and places those concerns on an equal level with those occurring within the United States territory. ${ }^{177}$

Another benefit provided by NEPA's extraterritorial application is that it could be used to fill in the gaps left by Executive Order 12,114. The Order was a step in the right direction because it recognized that there are some situations where NEPA should definitely be applied extraterritorially. However, the Order has so many exemptions and loopholes that, in most cases, its mandates are insufficient to protect the global environmental. Furthermore, one court has held that the order ${ }^{178}$ only applies to the global commons and not to the jurisdiction of any sovereign nation. Finally, the order is weakened by the fact that it does not provide for a private cause of action.

In spite of the benefits mentioned above, there are some equally good arguments against the extraterritorial application of NEPA. The biggest obstacle to requiring NEPA to be applied to international projects is the harm it could do to the United State's relationship with other nations. Specifically, the policy aspects that are cause for concern when determining extraterritorial application of NEPA is the sovereignty of foreign countries. ${ }^{179}$ For instance, in some situations, the appearance that the United States is imposing its environmental values on another country may offend that country's perceived sovereign right to utilize its own resources as it wishes.

However, NEPA provides a means for dealing with possible conflicts between the EIS requirement and foreign relation concerns. For

See Denise E. Antolini, Extending NEPA Is In Our National Interest, 8 Envtl. F., Nov./Dec.1991, at 26, 27 ("The extraterritorial application of NEPA would strengthen, not cripple, the United States' political and moral force by eliminating the double standard that honesty is warranted at home, but not abroad.").

See Emsdorfi, supra at 150.

178 Massey, $986 \mathrm{~F}, 2 \mathrm{~d}$ at 534 
instance, the introductory paragraph in section 102(2) requires all federal agencies to comply "to the fullest extent possible" with the requirements and policies set out in the statute such that an agency may bypass the EIS requirement if there is unavoidable conflict between its statutory authority and the EIS requirement. ${ }^{180}$ In addition, since NEPA is only a procedural statute, it does not mandate particular results. As a result, application of NEPA to projects outside the United States will not impose any substantive United States laws on other countries.

A further argument against applying NEPA extraterritorially is that the EIS process is time-consuming and expensive. Thus, opponents assert that if NEPA has to a be applied extraterritorially, it will place additional bureaucratic requirements that may damage relations with other countries and delay implementation of important international development projects. This is a legitimate concern because a key complaint against NEPA, in the United States, is that the EIS process is too long. Onc possible solution to this problem is to adopt the recommendation of the CEQ and allow for the preparation of a shorter foreign EIS. ${ }^{181}$

\section{THE FUTURE OF NEPA'S EXTRATERRITORIAL APPLICATION}

As part III of this paper indicates neither the legislature, executive, or judicial branches has reached a definitive conclusion regarding the extraterritorial application of NEPA. As this defines the current state of the law, it is difficult to predict whether or not NEPA will be applied extraterritorially in the future. The only thing certain is that the question of the extraterritoriality of NEPA remains open. However, a review of the various interpretations does provide some guidance on the subject.

\subsection{Possible Congressional Action}

Congress has made several attempts to amend NEPA so that it explicitly states that it applies extraterritorially, but none of the bills have passed. For example, in 1989, a bill that eventually failed was introduced in the Senate to amend NEPA to apply extraterritorially. ${ }^{182}$ That amendment would have changed section $102(2)(C)$ by inserting the following language after "major

180 See NEPA, 42 U.S.C. at $\S 4332$.

1BI See Council on Environmental Quality Draft Regulations, reprinted in 8 Env't Rep. (BNA) at 1495 .

182 S. $1089 \mathrm{sl}($ b)(1), 101 st. Cong., 1st Sess., 135 Cong. Rec. S5990 (daily ed. June 1, 1989). 
federal actions": "including extraterritorial actions (other than those taken to protect the national security of the U.S., actions taken in the course of armed conflict, strategic intelligence actions, armament transfers, or judicial or administrative, civil or criminal enforcement actions)."183

The proposed bill also sought to amend section 204 of NEPA to require the promulgation of NEPA regulations to assure "full consideration of the environmental impacts of proposed major Federal actions on geographic, oceanographic, and atmospheric areas within as well as beyond the jurisdiction of the United States and its territories and possessions." 184 The failure of that bill and others like it indicates that Congress is not yet ready to expand the scope of NEPA. Given the current leadership in Congress and the opposition of members of the business community, it is highly unlikely that NEPA will be amended to apply extraterritorially.

\subsection{Possible Executive Action}

\subsubsection{Possible Action By CEQ}

From its initial creation, CEQ has pushed for NEPA's extraterritorial application. However, CEQ has been forced, on numerous occasions, to retreat from its position. In recent years, CEQ has been too busy fighting for its continued existence to deal with the extraterritoriality issuc.

For example, during the Reagan Administration, the agency's resources were drastically reduced, and have never been restored to pre-Reagan levels. ${ }^{185}$ Further, in February of 1993, President Clinton stated his intention to ask Congress to abolish CEQ and replace it with a nonstatutory Office on Environmental Policy within the White House. The plan met with resistance from Congress and the President relented, and the former White House staff office has been merged into CEQ. ${ }^{186}$ Unfortunately, CEQ is still under-staffed and lacking the necessary resources to do the job it was created to do. Thus, it is doubtful that any future action by CEQ wil! increase the likelihood of NEPA being applied extraterritorially.

\subsubsection{Possible Presidential Action}

183 Id.

184 S. 1089 at s l(b)(l).

185 Gordon J. MacDonald, Assessing the US. environment: environmental quality: The Twenty-fourth Annual Report of the Council on Environmental Quality (CEQ). ENVIRONMENT, March 1, 1996 at 25-26. 
Since early 1993 , consideration has been given to the possible modification of Executive Order 12114 to apply NEPA-like environmental impact analysis requirements to major federal actions overseas. ${ }^{187}$ However, attempts to make the mandates of the order as expansive as those of NEPA has met with strong opposition. The key opponents have been politically powerful multinational corporations and federal agencies like the Department of Defence. In spite of protests from these group, some federal agencies have voluntarily prepared EISs for their international projects. Given the political clout of his opponents, it is unlikely that the President will issue an executive order that directly calls for the extraterritorial application of NEPA.

Nonetheless, President Clinton did issue executive orders directing that the North American Agreement on Environmental Cooperation ${ }^{188}$ and the agreement between the United States and the United Mexican States concerning the establishment of a Border Environment Cooperative Commission ${ }^{189}$ be implemented in a manner consistent with United States environmental policy. This action indicates that the executive branch is concern about the global environment.

\subsection{Possible Judicial Interpretation}

Since it does not appear that the current state of the law will be changed, it is necessary to look to the judiciary to get some idea of whether or not NEPA will be applied extraterritorially in the future. In an attempt to foretell how the next NEPA extraterritoriality case coming before the court will be decided, it is necessary to review the principles/tests established by the key cases that have addressed the issue.

It is well accepted that if the actions and the effects are both domestic, there is no issue of extraterritoriality. Hence, NEPA and its environmental impact statement requirement will apply to any major federal actions involved. When the agency action occurs outside of the United States but the effects of such action might be felt within United States borders, NEPA's EIS requirement is probably applicable. Two cases have assumed it was applicable without so deciding under such circumstances. ${ }^{190}$ Also, application of the effects doctrine that is used to evaluate the extrater-

187 Presidential Review Directive/NSC-23, U.S. Policy on Extraterritorial Application of the National Environmental Policy Act (NEPA) (8 Apr. 1993).

Exec. Order No. 12,915 (1994).

189

Exec. Order No. 12,916 (1994).

190

Sierra Chub, 578 F.2d at 392 n. 14; NORML, 452 F. Supp. at 1233. 
ritoriality of economic regulations will lead to the conclusion that NEPA applies extraterritorially in these types of situations. ${ }^{191}$

If the actions are taken inside the United States, but the effects of those actions are felt beyond U.S. domestic borders, NEPA will probably apply under a broad reading of Massey. This is a probable outcome because the Massey court focussed upon where the conduct took place and not on its effects to conclude that the presumption against extraterritoriality did not apply. ${ }^{192}$ Once the presumption was removed, NEPA was given effect. The court reasoned that since the federal decision-making process which resulted in the challenged activity occurred in the United States, it was appropriate to apply NEPA.

Finally, when agency actions and effects both occur outside the United States, it is extremely difficult to predict the outcome of the case. The results will vary based upon different interpretations of the judicial precedent. For example, one reading of Massey may lead one to argue that the EIS requirement will always apply to such major federal actions because the focus of the inquiry should be on the conduct regulated by the statute and not on the location of the effects of that regulation.

Another possible reading of the case would permit one to argue that the court should consider the location of the action and its effects in determining the applicability of the presumption. Under that reading, if the action and effects occur in the global commons (i.e., Antarctica, the high seas, outer space, etc.), then an EIS is required. However, in territory governed by another sovereign, separation of powers and international comity concerns may weigh against extraterritorial application. ${ }^{193}$ This reading of the case is more in keeping with the reasoning of the Massey court. That court emphasized that Massey should be given a narrow reading because of the uniqueness of Antarctic as a continent without a sovereign. 194

\section{Conclusion}

See Goldfarb, supra at 600-602; see also NRDC, 647 F.2d at 1368.

Massey, 986 F.2d at 533 .

e.g. Nalural Resources Defense Council v. Nuclear Regulatory Comm'n, 647 F.2d 1345 (D.C. Cir. 1981).

Massey, 986 F.2d at 534 . 
Environmental pollution, in all forms, is a part of our daily lives. The international community recognized that all ecosystems are connected and environmental problems are transboundary. Thus, no country is unaffected. That recognition caused countries to work together and organize meetings like the Rio Convention in order to come up with solutions to the problems. Several countries have also followed the United States' lead and implemented statutes similar to NEPA. NEPA was passed to announce the national environmental policy of the United States. Since its passage, NEPA has been heavily litigated. Most of the litigation has dealt with the EIS requirement. The focus of this paper is on the issue of the extraterritorial application of NEPA. After reviewing the materials written about the subject and the judicial precedents, it is still unclear whether or not NEPA should be applied extraterritorially.

On the one hand, the language of the statute and part of the legislative history implies that Congress was concerned with the planet and not just the nation. Nonetheless, it is not clear to what extent NEPA was meant to be applied outside of the United States.

The executive, congressional and judicial branches have not provided a definitive answer to the extraterritoriality question. Soon after the enactment of the statute, the Council on Environmental Quality was the only division of the executive branch to make a clear declaration on the issue. However, the Council has been forced to retreat from its position that NEPA was meant to be applied extraterritorially.

For its part, the executive branch stated its position in an executive order that only served to further confuse the issue. The issuance of the executive order was a positive action because it did require agencies to consider the environmental consequences of their international actions. In an attempt to clarify the issue, Congress has tried unsuccessfully to amend NEPA to make it apply to actions outside-of the United States, but opponents of that position have proven to be too strong. The courts have weighed in on the issue, but have left open the question of whether it is appropriate to apply NEPA to activities in a foreign land that is not considered to be a global common.

On balance, there is a strong argument that the reasons to apply NEPA extraterritorially outweigh the reasons not to apply it. Since environmental pollution is rarely contained in a geographic area, inevitably, activities that affect the environment in a foreign country will affect the United States environment. Thus, it makes sense that the requirements of NEPA be applied to those activities, especially since the United States agencies are key participants in them. The primary argument against applying NEPA extraterritorially deal with foreign relations. In short, opponents argue that the United States should not impose its environmental 
laws on other countries. This argument is weakened by the fact that NEPA gives agencies the discretion to exempt a project for foreign policy reasons. Further, NEPA is only procedural and does not mandate the application of other United States laws.

Today, there is a recognition by the international community that all ecosystems are connected and that cooperation between nations is needed to work to clean up the environment. In light of this recognition, some day NEPA may be amended to apply extraterritorially. Even if that does not happen, the courts may rely upon the reasoning in the antitrust and securities cases to rule that it is reasonable to apply NEPA extraterritorially. 


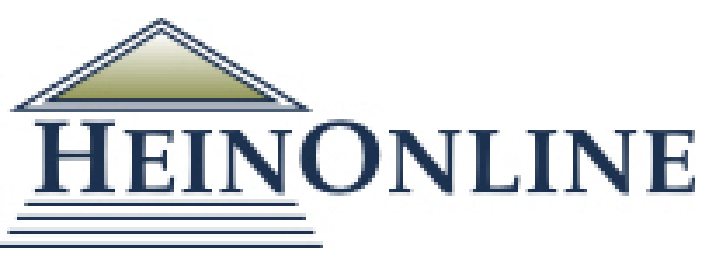

Content downloaded/printed from

HeinOnline

Mon Oct 21 15:56:50 2019

Citations:

Bluebook 20th ed.

Browne Lewis, Analysing the Extraterritorial Application of the National

Environmental Policy Act, 8 Tilburg Foreign L. Rev. 313 (1999).

ALWD 6th ed.

Browne Lewis, Analysing the Extraterritorial Application of the National

Environmental Policy Act, 8 Tilburg Foreign L. Rev. 313 (1999).

APA 6th ed.

Lewis, B. (1999). Analysing the extraterritorial application of the national environmental policy act. Tilburg Foreign Law Review, 8(4), 313-346.

Chicago 7th ed.

Browne Lewis, "Analysing the Extraterritorial Application of the National

Environmental Policy Act," Tilburg Foreign Law Review 8, no. 4 (1999-2000): 313-346

McGill Guide 9th ed.

Browne Lewis, "Analysing the Extraterritorial Application of the National

Environmental Policy Act" (1999) 8:4 Tilburg L Rev 313.

MLA 8th ed.

Lewis, Browne. "Analysing the Extraterritorial Application of the National

Environmental Policy Act." Tilburg Foreign Law Review, vol. 8, no. 4, 1999-2000, p.

313-346. HeinOnline.

OSCOLA 4th ed.

Browne Lewis, 'Analysing the Extraterritorial Application of the National

Environmental Policy Act' (1999) 8 Tilburg Foreign L Rev 313

Provided by:

Cleveland-Marshall College of Law Library

-- Your use of this HeinOnline PDF indicates your acceptance of HeinOnline's Terms and Conditions of the license agreement available at https://heinonline.org/HOL/License

-- The search text of this PDF is generated from uncorrected OCR text.

-- To obtain permission to use this article beyond the scope of your license, please use: Copyright Information

Use QR Code reader to send PDF to your smartphone or tablet device

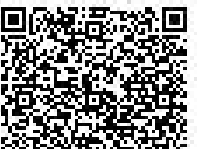

